\title{
Adaptation of an empirical model for erythemal ultraviolet irradiance
}

\author{
I. Foyo-Moreno ${ }^{1}$, I. Alados ${ }^{2}$, and L. Alados-Arboledas ${ }^{1}$ \\ ${ }^{1}$ Dpto de Física Aplicada, Universidad de Granada, Granada, Spain \\ ${ }^{2}$ Dpto de Física Aplicada II, Universidad de Málaga, Málaga, Spain
}

Received: 20 March 2006 - Revised: 18 June 2007 - Accepted: 27 June 2007 - Published: 30 July 2007

\begin{abstract}
In this work we adapt an empirical model to estimate ultraviolet erythemal irradiance (UVER) using experimental measurements carried out at seven stations in Spain during four years (2000-2003). The measurements were taken in the framework of the Spanish UVB radiometric network operated and maintained by the Spanish Meteorological Institute. The UVER observations are recorded as half hour average values. The model is valid for all-sky conditions, estimating UVER from the ozone columnar content and parameters usually registered in radiometric networks, such as global broadband hemispherical transmittance and optical air mass. One data set was used to develop the model and another independent set was used to validate it. The model provides satisfactory results, with low mean bias error (MBE) for all stations. In fact, MBEs are less than $4 \%$ and root mean square errors (RMSE) are below 18\% (except for one location). The model has also been evaluated to estimate the UV index. The percentage of cases with differences of 0 UVI units is in the range of $61.1 \%$ to $72.0 \%$, while the percentage of cases with differences of \pm 1 UVI unit covers the range of $95.6 \%$ to $99.2 \%$. This result confirms the applicability of the model to estimate UVER irradiance and the UV index at those locations in the Iberian Peninsula where there are no UV radiation measurements.
\end{abstract}

Keywords. Atmospheric composition and structure (Aerosols and particles; Transmission and scattering of radiation) - Meteorology and atmospheric dynamics (Radiative processes)

\section{Introduction}

Solar radiation sustains and affects all life forms on the Earth. Solar irradiance in the UV range $(280-400 \mathrm{~nm})$ is known to produce significant environmental effects (UNEP, 1998,

Correspondence to: I. Foyo-Moreno

(ifoyo@ugr.es)
2003). Small amounts of solar ultraviolet radiation are beneficial for people and essential in the production of vitamin $D_{3}$ for building and maintaining bones (Bryant, 1997), but the major effects of the shorter wavelength region reaching the Earth are harmful to many organisms, causing DNA damage (Diffey, 1992). Excessive UV exposure may lead to damage of the skin, eyes and immune systems of humans and animals, and can also harm terrestrial plants and aquatic systems.

The discovery of the Antarctic ozone hole and the decline of the ozone layer in mid-latitudes has increased concern about levels of UV radiation (WMO, 1998), and this presents a serious environmental issue (Lebert et al., 2002; Ma and Guicherit, 1997). In Brazil, covering tropical and subtropical regions, the damage caused by sunlight exposure is responsible for the highest-incident cancer type in the country: skin cancer (Brazilian Society of Dermatology, 2003). Incidence and mortality rates due to skin cancer in Australia are among the highest in the world, with two out of three Australians developing some form of skin cancer in their lifetime (Turbull and Parisi, 2003). Since 1973 the annual growth rate for cases of malignant melanoma has been quantified at $4 \%$ (ACS, 1995), while the United Nations Environment Program (UNEP) has estimated that every year there are more than 2 million melanoma skin cancer cases and some 200000 cases of malignant melanomas.

Ultraviolet radiation, which composes $8.73 \%$ of the solar spectrum in outer space (ASTM, 1973) is usually divided into three bands (CIE, 1987): UV-C (100-280 nm), which is completely absorbed by stratospheric ozone, UV-B (280$315 \mathrm{~nm}$ ), which is only partially absorbed or scattered in the atmosphere, and UV-A (315-400 nm), which makes up most of the UV irradiance at the surface. Considering the solar spectral irradiance in outer space, UV-B and UV-A bands account for only about $7.45 \%$ of the total solar radiation (Fröhlich and London, 1986), although at the surface they typically make up between $3 \%$ and $5 \%$ of the solar total irradiance (Foyo-Moreno et al., 1998).

Published by Copernicus Publications on behalf of the European Geosciences Union. 
Recently, the interest of the scientific community has been focused on the study of UV-B radiation, principally due to its harmful effects on biological systems (Diffey, 1991; Van der Leun et al., 1991, 1994, 1998; Zerefos at al., 2001). For human beings, the effect that has received most attention is the erythema, or sunburn. An index that is recognized internationally as a standard for determining the risk associated with UV-B radiation is the erythemal irradiance (UVER). This is calculated by weighting the spectral curve of the incident solar radiation at the surface with the spectral action curve proposed by the "Commission Internationale de l'Eclairage" (McKinlay and Diffey, 1987). The action spectrum (Diffey, 1982) has an absolute maximum at $297 \mathrm{~nm}$.

When solar extraterrestrial UV radiation enters the atmosphere, it interacts with atmospheric constituents (air molecules, aerosol particles, droplets and ice particles). The variability of different constituents, especially the high temporal and spatial variability of cloud cover and aerosols, as well as the position of the Sun in the sky, determine the variability of radiation received on the ground. Given the major role played by the UV solar radiation received at the Earth's surface and the importance of its characterisation, recent years have seen a substantial increase in attempts to model UV solar radiation. However, only recently have the network stations measuring this radiometric flux begun to increase and so much remains to be learned.

To model the influence of clouds and aerosols on UV solar radiation is difficult, since there is a general lack of observations for aerosols and the effects of the clouds are complex to quantify. Different methodologies have been used to analyse the effects of clouds on this radiometric flux, including radiative transfer models and empirical approaches. The first method implies the application of Mie theory and requires input information, such as cloud optical thickness and droplet size distributions with high temporal and spatial resolution, information that is limited to specific sites and campaigns. The second method attempts to estimate the UV radiation from parameters usually measured at most radiometric stations. Calbó et al. (2005) have carried out a detailed revision of empirical studies of cloud effects on UV radiation. These empirical models are based on visual observations of cloud amount alone or in combination with other cloud features (Ilyas, 1987; Frederick et al., 1990, 1993; Blumthaler et al., 1994, 1996; Thiel et al., 1997; Kuchinke and Nunez, 1999; Lubin and Frederick, 1991; Bais et al., 1993; Nemeth et al., 1996), on information obtained with sky cameras and satellite cloud retrieval techniques (Borkowski et al., 1977; Shafer et al., 1996; Sabburg and Wong, 2000; Josefsson and Landelius, 2000), on information retrieved by radiative measurements, or on combined information from radiative measurements and observations of clouds (Frederick and Steele, 1995; Bordewijk et al., 1995; Bodeker and McKenzie, 1996; Foyo-Moreno et al., 1998; Estupiñán et al., 1996; Grant and Heisler, 2000; den Outer et al., 2005).
Previous works (Alados-Arboledas et al., 2003; Alados et al., 2004) have characterised the cloud effects on UVER using information routinely registered in most meteorological stations: cloud type and amount, expressed in terms of fractional cloud coverage in octas (eighths). On the other hand, Foyo-Moreno et al. (1999) developed an empirical model to estimate the ultraviolet solar radiation in the range of 295$385 \mathrm{~nm}$ for all-sky conditions. This model, revised recently by Calbó et al. (2005), uses as input a set of parameters usually available in radiometric networks, such as the broadband global solar irradiance and the optical air mass. In particular, the model uses the hemispherical transmittance $\left(k_{t}\right)$, defined as the ratio of global horizontal irradiance to extraterrestrial horizontal irradiance, a parameter that depends on the cloud cover and aerosol load. In this work, we have adapted the model to estimate UVER for several stations of the Iberian Peninsula with rather different environments. To do this we have included as an additional input parameter the ozone columnar content. Data from Madrid have been used to develop the model that has been validated with the independent data sets recorded at the remaining sites.

\section{Data and measurements}

The UVER observations, performed within the Spanish UV$B$ radiometric network, were recorded as half-hour average values, although these instruments in their standard operation mode, take measurements of ultraviolet erythemal radiation every second. From these values the integrated irradiation is found for the desired time interval, hourly average values in our case.

Martinez-Lozano et al. (2002) reported a detailed description of this network. Yankee UVB-1 radiometers are operated and maintained by the Spanish Meteorological Institute (INM). Only clear sky data are used in the determination of the erythemal calibration factors. These factors are modelled as a function of zenith angle and total ozone, following the so-called indirect method. The calibration methodology of these instruments has been described by Lantz et al. (1999). The Yankee UVB-1 radiometer is a broadband (280-315 nm) Robertson-Berger type radiometer. The spectral response of the instrument is designed to approximate the spectral response of the human skin to UV (McKinlay and Diffey, 1987). The experimental uncertainty of this instrument is about 8-9\% (Leszczynski et al., 1998; Pearson et al., 2000).

Solar global irradiance has been registered on an hourly basis using a Kipp \& Zonen model CM-11, while another Kipp \& Zonen model C-11 with a polar axis shadowband was used to measure solar diffuse irradiance. Measurements of solar global and diffuse irradiance have an estimated experimental error of about 2-3\%.

Data were registered at Madrid $\left(40^{\circ} 27^{\prime} \mathrm{N}, 3^{\circ} 44^{\prime} \mathrm{W}, 580 \mathrm{~m}\right.$ above sea level (a.s.l.)), A Coruña $\left(43^{\circ} 21^{\prime} \mathrm{N}, 8^{\circ} 25^{\prime} \mathrm{W}\right.$, 
$67 \mathrm{~m}$ a.s.1.), Málaga $\left(36^{\circ} 43^{\prime} \mathrm{N}, 4^{\circ} 29^{\prime} \mathrm{W}, 61 \mathrm{~m}\right.$ a.s.1.), Santander $\left(43^{\circ} 29^{\prime} \mathrm{N}, 3^{\circ} 48^{\prime} \mathrm{W}, 63 \mathrm{~m}\right.$ a.s.l.), Zaragoza $\left(41^{\circ} 38^{\prime} \mathrm{N}\right.$, $0^{\circ} 55^{\prime} \mathrm{W}, 250 \mathrm{~m}$ a.s.l.), during the period 2000-2003, Valencia $\left(39^{\circ} 29^{\prime} \mathrm{N}, 0^{\circ} 22^{\prime} \mathrm{W}, 11 \mathrm{~m}\right.$ a.s.l.) during the years 2000 , 2001 and 2003 and Murcia $\left(38^{\circ} 00^{\prime} \mathrm{N}, 1^{\circ} 10^{\prime} \mathrm{W}, 69 \mathrm{~m}\right.$ a.s.l.) during the year 2000. Madrid and Zaragoza are inland locations more than $200 \mathrm{~km}$ from the coast; Murcia is an inland location about $50 \mathrm{~km}$ from the Mediterranean Sea; whereas Valencia and Málaga are coastal locations situated in the western Mediterranean. A Coruña and Santander are located on the Atlantic coast of the Iberian Peninsula.

In the stations selected for this study, simultaneous observations of ozone columnar content were performed using the Brewer instrument operated within the same network at the selected locations. Columnar ozone content is not measured at all the stations. After analysing the available measurements and considering the marked latitudinal pattern of this variable, different criteria have been used for the assignation of ozone columnar content at stations where measurements were not available. Thus, for Málaga we have used the measurements performed at El Arenosillo, the closest station that also presents a similar latitude. A similar procedure has been followed at Santander that uses the data set registered at A Coruña. Finally, for Valencia we used the average between Madrid and Murcia.

The Madrid data were used to develop the model, and data from the other stations were used in the evaluation of the model. To avoid problems associated with deviations by the instrument from the ideal cosine law, we limited our study to solar elevation angles greater than $10^{\circ}$; in any case, the UVER values measured for larger zenith angles are relatively small.

Figure 1 shows a histogram with the relative frequency for the broadband hemispherical transmittance $\left(k_{t}\right)$ at all sites employed in the evaluation of model, in order to characterise atmospheric conditions for the period under study. This parameter is defined as the ratio of the global irradiance to the extraterrestrial irradiance, both on a horizontal surface. We can observe that the cities which present a great number of cases with high $k_{t}$ are Murcia, Málaga and Zaragoza, with $84 \%, 81 \%$ and $80 \%$, respectively, of cases with $k_{t}$ higher than 0.5. The cities with a higher number of cases with $k_{t}$ lower than 0.5 are Santander and A Coruña, with a percentage of 41 and 35\%, respectively. For the period 19712000 , we obtained monthly and yearly climatic data from http://www.inm.es for stations analysed in this study. Table 1 shows some climatic data for stations analysed in this study. Especially relevant are the differences in yearly precipitation, relative humidity and sunshine duration. In terms of climatology Málaga and A Coruña and Santander present extremes among our sites, Málaga representative of the Mediterranean climates, and A Coruña and Santander of the maritime climates. Málaga presents high maximum mean temperature and a mild minimum temperature with sparse cloudiness and precipitation, and Santander and A Coruña present mild tem-

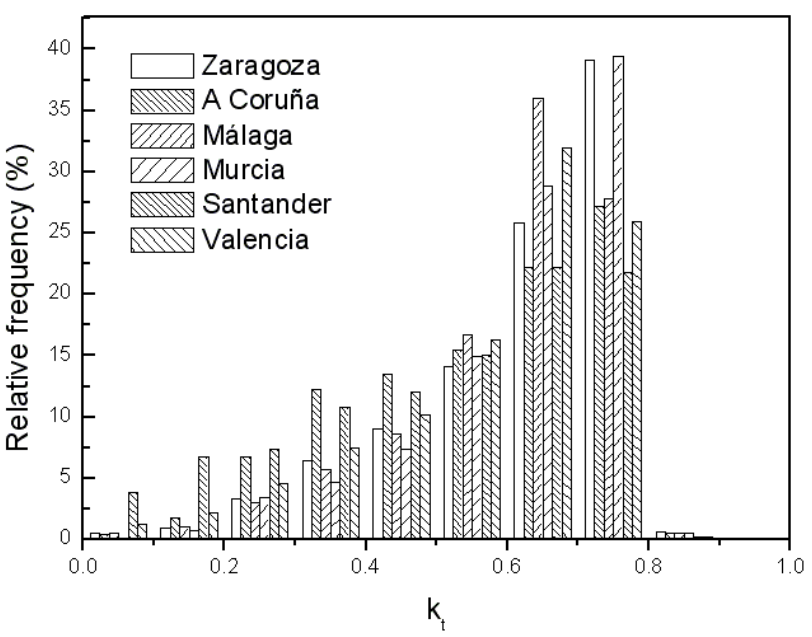

Fig. 1. Histograms of the global broadband hemispherical transmittance $\left(k_{t}\right)$ at each location for the study period.

peratures for the entire year, increased cloudiness and high precipitation. The station with climatic conditions most similar to Madrid is Zaragoza, with severe winters and warm summers. To some degree, the sites used in this study are representative of the climatic variety of the Iberian Peninsula.

\section{Results}

\subsection{Estimation model}

The optical air mass and cloudiness conditions are the most important factors to be considered in order to estimate the UVER global irradiance. Accordingly, Krzyscin and Sobolewski (2001) affirmed that the main UVER day-to-day variability is induced by clouds and aerosol and not by ozone content. Also, Lubin et al. (1998) showed that the main variability of UV radiation in otherwise homogenous regions comes from cloudiness.

Temporal resolutions of the measurements are variable; some of them are instantaneous while most of them are averages from $5 \mathrm{~min}$ to $1 \mathrm{~h}$. This is a problem for models that consider direct information on cloudiness, usually an instantaneous observation. When sky conditions change considerably during the averaging time, the matching of averaged radiation measurements with instantaneous cloud observations may yield confusing results (Calbó et al., 2005). Therefore, low variability of cloudiness should be guaranteed when making use of an instantaneous measurement instead of an averaged value (Schwander et al., 2002). This problem disappears when using broadband irradiance measurements as the only input parameter, because both variables (UV and broadband irradiances) can be obtained with the same time interval. This represents an advantage of the empirical model 
Table 1. Climatic data for the analyzed stations for the period 1971-2000.

\begin{tabular}{lccccccc}
\hline $\begin{array}{l}\text { Station } \\
(1971-2000)\end{array}$ & $\mathrm{T}$ & $\mathrm{TM}$ & $\mathrm{Tm}$ & $\mathrm{R}$ & $\mathrm{H}$ & $\mathrm{DD}$ & $\mathrm{I}$ \\
\hline $\begin{array}{l}\text { A Coruña } \\
\left(43^{\circ} 21^{\prime} \mathrm{N}, 8^{\circ} 25^{\prime} \mathrm{W}, 67 \mathrm{~m} \text { a.s.l. }\right)\end{array}$ & 14.4 & 17.4 & 11.4 & 1008 & 77 & 48 & 1966 \\
$\begin{array}{l}\text { Madrid } \\
\left(40^{\circ} 27^{\prime} \mathrm{N}, 3^{\circ} 44^{\prime} \mathrm{W}, 580 \mathrm{~m} \text { a.s.l. }\right)\end{array}$ & 14.1 & 20.6 & 7.6 & 386 & 59 & 94 & 2658 \\
$\begin{array}{l}\text { Málaga } \\
\left(36^{\circ} 43^{\prime} \mathrm{N}, 4^{\circ} 29^{\prime} \mathrm{W}, 61 \mathrm{~m} \text { a.s.l. }\right)\end{array}$ & 18.0 & 22.9 & 13.1 & 524 & 66 & 107 & 2815 \\
$\begin{array}{l}\text { Murcia } \\
\left(38^{\circ} 00^{\prime} \mathrm{N}, 1^{\circ} 10^{\prime} \mathrm{W}, 69 \mathrm{~m} \text { a.s.l. }\right)\end{array}$ & 17.8 & 24.4 & 11.2 & 301 & 59 & 94 & 2797 \\
$\begin{array}{l}\text { Santander } \\
\left(43^{\circ} 29^{\prime} \mathrm{N}, 3^{\circ} 48^{\prime} \mathrm{W}, 63 \mathrm{~m} \text { a.s.l. }\right)\end{array}$ & 14.1 & 18.1 & 10.2 & 1246 & 75 & 38 & 1638 \\
$\begin{array}{l}\text { Valencia } \\
\left(39^{\circ} 29^{\prime} \mathrm{N}, 0^{\circ} 22^{\prime} \mathrm{W}, 11 \mathrm{~m} \text { a.s.l. }\right)\end{array}$ & 17.8 & 22.3 & 13.4 & 454 & 65 & 91 & 2660 \\
$\begin{array}{l}\text { Zaragoza } \\
\left(41^{\circ} 38^{\prime} \mathrm{N}, 0^{\circ} 55^{\prime} \mathrm{W}, 250 \mathrm{~m} \text { a.s.l }\right)\end{array}$ & 15.0 & 20.4 & 9.5 & 318 & 62 & 80 & 2614 \\
\hline
\end{tabular}

T: Yearly average temperature $\left({ }^{\circ} \mathrm{C}\right)$

TM: Yearly average of the maximum temperature $\left({ }^{\circ} \mathrm{C}\right)$

Tm: Yearly average of the minimum temperature $\left({ }^{\circ} \mathrm{C}\right)$

$\mathrm{R}$ : Yearly average of precipitation ( $\mathrm{mm})$

$\mathrm{H}$ : Yearly average of relative humidity $(\%)$

DD: Yearly average of cloudless days

I: Yearly average of sunshine duration

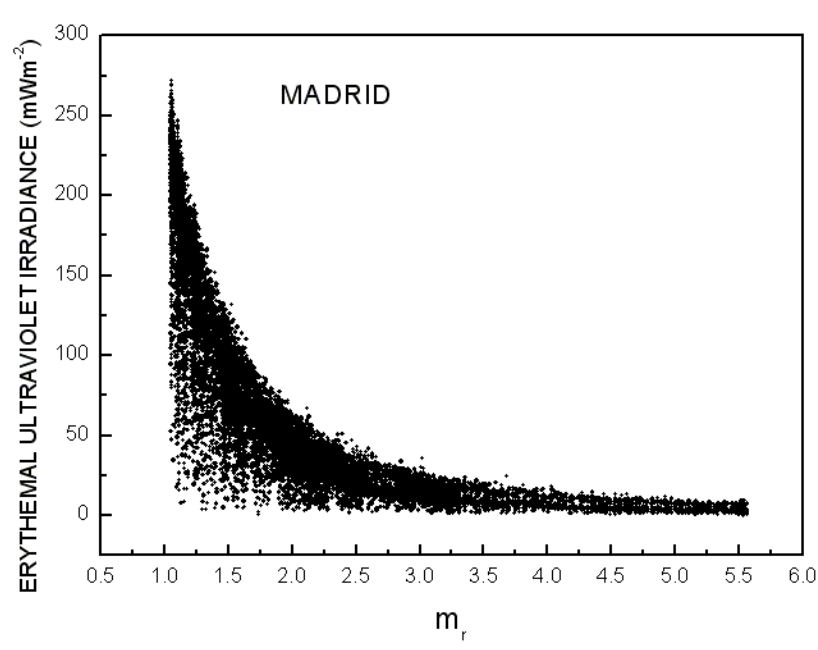

Fig. 2. Erythemal ultraviolet irradiance (UVER) versus optical air mass $\left(m_{r}\right)$ at Madrid.

adapted here because the input parameter is not direct information about cloudiness but rather the broadband global irradiance in terms of $k_{t}$. After a detailed analysis studying the relation between ultraviolet global irradiance and broadband global irradiance, Foyo-Moreno et al. (1999) proposed a simple expression to estimate ultraviolet solar radiation (295$385 \mathrm{~nm}$ ) from only two input variables: clear-sky ultraviolet irradiance and the $k_{t}$ parameter. A detailed description of the model is given by Foyo-Moreno et al. (1999).

In the next paragraphs we describe the adaptation of the previous UV model (Foyo-Moreno et al., 1999) to UVER. To do this we have included as an additional input parameter the ozone columnar content.

Figure 2 plots UVER global irradiance versus optical air mass at Madrid. This figures indicates that solar elevation alone does not allow for a correct determination of UVER global irradiance, but it can be concluded that the radiation values decrease with increasing air mass, although with high dispersion, and that a parameterization of the enveloping curve is possible. These data are maximum values for UVER global irradiance, logically associated with cloudless sky values. In Foyo-Moreno et al. (1999) we have used this approach by fitting the enveloping curve of UV $(295-385 \mathrm{~nm})$ to an exponential model:

$\mathrm{UV}_{o}(295-385)=A+A^{\prime} e^{-\cdot \frac{m_{r}}{B^{\prime}}}+A^{\prime \prime} e^{-\frac{m_{r}}{B^{\prime \prime}}}$,

where $A, A^{\prime} A^{\prime \prime}, B^{\prime}$ and $B^{\prime \prime}$ are fitting parameters and the subscript zero refers to clear conditions.

In the case of UVER we must include explicitly the dependence on ozone columnar content. For this reason we have based the modelling of UVER under cloudless conditions on the procedure followed for UV (295-385 nm), with some modification. In this sense we have obtained a subset of cloudless conditions data using the criterion of AladosArboledas et al. (2000), thus avoiding the enveloping of 


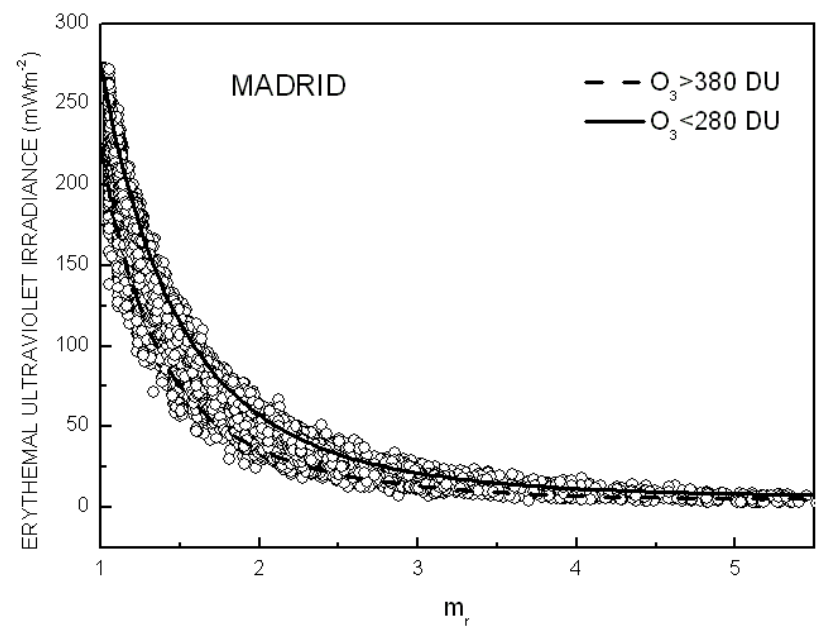

Fig. 3. Erythemal ultraviolet irradiance (UVER) versus optical air mass $\left(m_{r}\right)$ at Madrid (clear skies).

Fig. 2 that would be biased towards the lower values of ozone columnar content. Figure 3 represents the dependence on optical air mass of UVER data corresponding to cloudless conditions. An exponential decay model can be used to fit the data:

$\mathrm{UVER}_{o}=A_{o}+A_{1} e^{-\frac{m_{r}}{B_{1}}}+A_{2} e^{-\frac{m_{r}}{B_{2}}}$,

where $A_{o}, A_{1}, A_{2}, B_{1}$ and $B_{2}$ are fitting parameters and the subscript zero refers to clear conditions. Table 2 shows the adjusted values for the coefficients in Eq. (2). The spread of the data shown in Fig. 3 suggests the inclusion of an additional parameterization on ozone columnar content. For this purpose we have divided the cloudless data set considering different intervals of ozone columnar content. Each subset has been fitted to the exponential function (Eq. 2). Considering the functional form of Eq. (2), some coefficients present small variability with the ozone columnar content. In this sense the coefficient $A_{o}$, associated with the asymptotic value of UVER for increasing optical air mass, and the decaying constant $B_{1}$ and $B_{2}$, have been fixed to the values obtained for the whole data set. Finally, only the amplitude coefficient $A_{1}$, associated with the fastest exponential decay, has been parameterized in terms of ozone columnar content, because it presents the largest dependence on this variable. Table 3 includes the amplitude coefficient $A_{1}$ values associated with the different ozone columnar content intervals considered. As is evident from Table 3 the coefficient $A_{1}$ decreases as the ozone columnar content increases. In this sense, the coefficient $A_{1}$ explains the increased attenuation of UVER when ozone columnar content increases.

In Fig. 3, we have included the model curves for two different values of ozone columnar content; this can be considered representative of the extreme cases of ozone columnar content in the study region. Thus, the variability of the dependence of $\mathrm{UVER}_{o}$ on optical air mass can be explained in
Table 2. Fitting values for coefficients in Eq. (2).

\begin{tabular}{ccccc}
\hline $\begin{array}{c}A_{o} \\
\mathrm{~mW} \mathrm{~m}^{-2}\end{array}$ & $\begin{array}{c}A_{1} \\
\mathrm{~mW} \mathrm{~m}^{-2}\end{array}$ & $\begin{array}{c}A_{2} \\
\mathrm{~mW} \mathrm{~m}^{-2}\end{array}$ & $B_{1}$ & $B_{2}$ \\
\hline $12.0 \pm 0.1$ & $1490 \pm 10$ & $124 \pm 1$ & $0.5 \pm 0.1$ & $0.8 \pm 0.1$ \\
\hline
\end{tabular}

Table 3. Coefficient $A_{1}$ for different intervals of ozone columnar content.

\begin{tabular}{lll}
\hline $\begin{array}{l}\text { Ozone } \\
(\mathrm{DU})\end{array}$ & $\begin{array}{l}\mathrm{A}_{1} \\
\mathrm{~mW} \mathrm{~m}^{-2}\end{array}$ & $\mathrm{r}^{2}$ \\
\hline$(260,270)$ & 1724 & 0.95 \\
$(270,280)$ & 1640 & 0.96 \\
$(280,290)$ & 1530 & 0.97 \\
$(290,300)$ & 1500 & 0.97 \\
$(300,310)$ & 1497 & 0.96 \\
$(310,320)$ & 1430 & 0.96 \\
$(320,330)$ & 1410 & 0.96 \\
$(330,340)$ & 1347 & 0.96 \\
$(340,350)$ & 1304 & 0.96 \\
$(350,360)$ & 1300 & 0.96 \\
$(360,370)$ & 1209 & 0.96 \\
$(370,380)$ & 1196 & 0.95 \\
$>380$ & 1070 & 0.95 \\
\hline
\end{tabular}

terms of the dependence of UVER on ozone columnar content.

Once the UVER global irradiance for clear skies is determined, the real value will depend on a given atmospheric situation. This situation can be characterized with the global broadband hemispherical transmittance $\left(k_{t}\right)$, a parameter that can be considered as a modulator of the maximum value. It is interesting to note that this parameter represents a hemispherical transmisivity that depends both on cloud cover and aerosol load. In a previous work (Foyo-Moreno et al., 1999) we have approached the use of a linear dependence of UV $(295-285 \mathrm{~nm})$ on the product of $\mathrm{UV}_{o}$ and $k_{t}$. In this work, after some considerations we settled on another expression that slightly improves the results mainly for high values of the product of $k_{t}$ and $\mathrm{UVER}_{o}$. This expression is a power relation:

$\mathrm{UVER}=A\left(k_{t} \mathrm{UVER}_{o}\right)^{B}$,

where $A=(1.50 \pm 0.01) \mathrm{mW} \mathrm{m}^{-2}$ and $B=(0.960 \pm 0.003)$ with a correlation coefficient of 0.985 and a standard error of $11.1 \mathrm{~mW} \mathrm{~m}^{-2}$. These fitting parameters have been obtained for experimental measurements carried out at Madrid. 

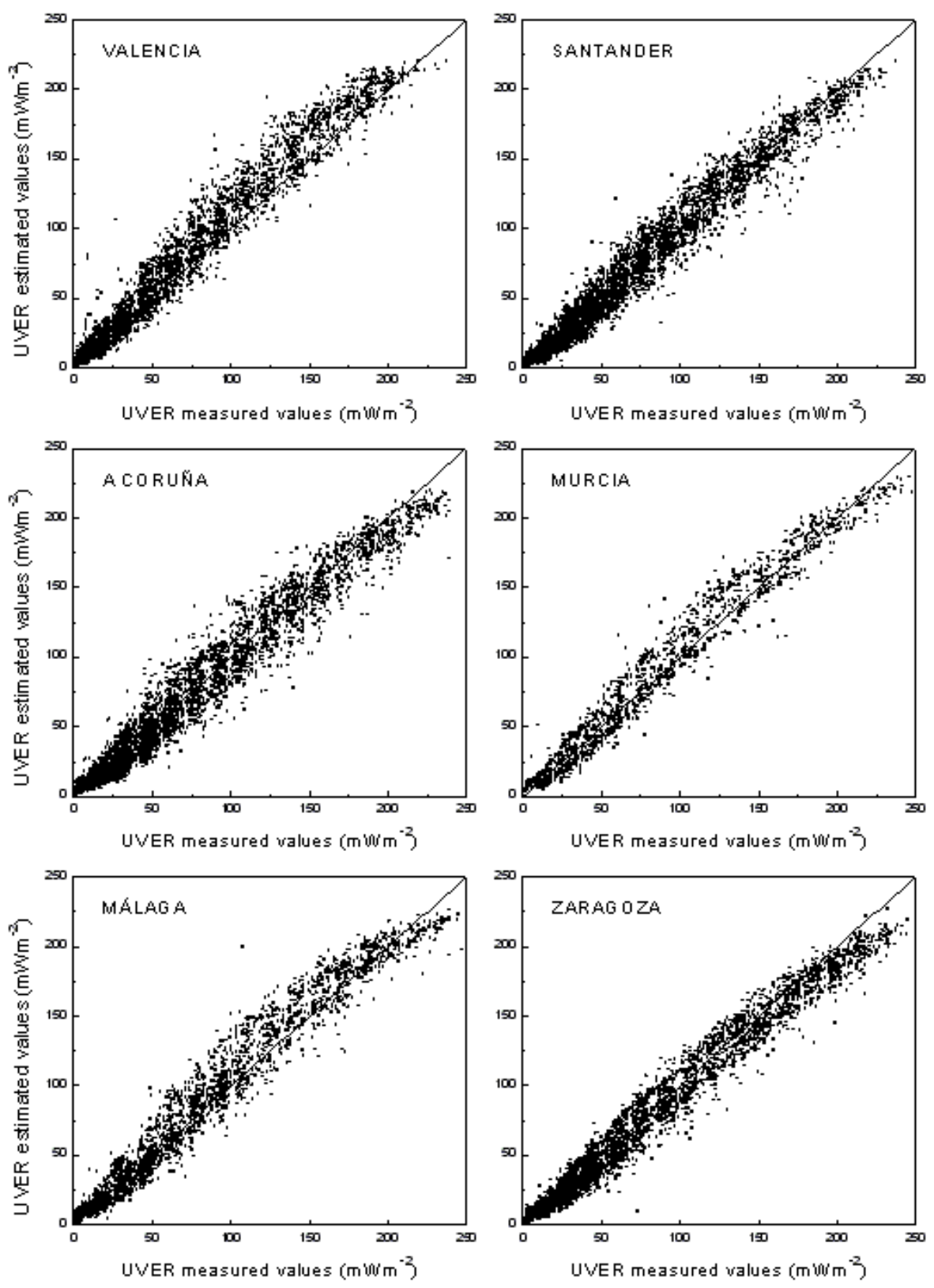

Fig. 4. Scatter plot of estimated versus measured UVER at each location.

\subsection{Model validation}

The model has been evaluated for the remaining sites which were not used in the calculation of the fitting parameters. Thus, to test portability and to validate the model we have used an independent database.

Table 4 shows the results obtained for every station including the determination coefficient $R^{2}$ (fraction of experimental data variance explained by the model), slope $b$, and intercept a, of the linear regression of UVER global measured versus estimated values. Also Table 4 shows the MBE and RMSE, both as a percentage of the mean experimental values; these two statistics allow for a detection of both the differences between experimental data and model estimates, and the existence of systematic over- or underestimation tendencies, respectively. Figure 4 shows the UVER global irradiance estimates by means of Eq. (3) at all study sites. For example, at Murcia, it can be observed that this model gives satisfactory results with a determination coefficient of 0.97 and a standard deviation of $11.42 \mathrm{~mW} \mathrm{~m}^{-2}$. The model evaluation is in general satisfactory for all radiometric stations, with a variance explained by the models exceeding $95 \%$ and the low values of MBE and RMSE. In fact, for three sites 
Table 4. Model results at each location.

\begin{tabular}{lrccrr}
\hline Stations & $\begin{array}{r}\mathrm{a} \\
\mathrm{mW} \mathrm{m}^{-2}\end{array}$ & $\mathrm{~b}$ & $R^{2}$ & $\begin{array}{r}\mathrm{MBE} \\
\%\end{array}$ & $\begin{array}{r}\mathrm{RMSE} \\
\%\end{array}$ \\
\hline A Coruña & 2.24 & 1.01 & 0.95 & -4.0 & 17.9 \\
Málaga & 2.39 & 1.01 & 0.96 & 3.7 & 16.2 \\
Murcia & 2.37 & 0.98 & 0.97 & 1.3 & 14.3 \\
Santander & -0.37 & 0.98 & 0.97 & -2.3 & 16.0 \\
Valencia & 2.43 & 1.07 & 0.96 & 10.3 & 21.0 \\
Zaragoza & 0.70 & 0.94 & 0.97 & -5.1 & 14.4 \\
\hline
\end{tabular}

the MBE values are lower than $4 \%$; only Valencia presents a larger value. The RMSE values do not exceed $18 \%$, except for Valencia $(21.0 \%)$. The model underestimates the UVER irradiance at three stations (A Coruña, Santander and Zaragoza). In any case, both the slope and correlation coefficient of the linear regression between measured and estimated values reveals the goodness of the estimation model.

A more detailed inspection of Fig. 4 reveals that the deviation between measured and estimated values is not uniform across the range of UVER values. Thus, the largest values are usually underestimated at different stations, excluding Valencia, where a general overestimation is seen. In the medium range of UVER values the model produces larger variability; this range corresponds to the medium range of solar zenith angles cases with variable cloudiness. At A Coruña, Santander and Zaragoza the scatter around the 1:1 line is almost symmetric in this medium range, while a more or less marked overestimation is evident at Valencia, Murcia and Málaga. These results suggest the need for additional improvements to the proposed model. In this sense, we have considered the inclusion of a solar-zenith-angle dependence. Nevertheless, the general underestimation in the largest values' range is due to the fitting equation selected in developing the cloudless model.

As mentioned above, den Outer et al. (2005) evaluated four parameterizations to estimate erythemal UV radiation with correlations between the ratios $\mathrm{UV} / \mathrm{UV}_{o}$ and $\mathrm{G} / \mathrm{G}_{o}$, two of which include dependence on the solar zenith angle. According to these authors, their best results correspond to the model that includes the solar zenith angle dependence. Therefore, we have developed a model including a solarzenith-angle dependence for the coefficients $A$ and $B$ of Eq. (3). To achieve this we binned the Madrid data according to solar zenith angle (Table 5) and computed the coefficients $A$ and $B$ of Eq. (3).

For the first two categories the coefficients are similar to those obtained for the model without solar-zenith-angle dependence. For solar zenith angles greater than $58^{\circ}$ the fitted coefficients differ markedly from those obtained without separation into solar-zenith-angles classes. The $R^{2}$ values obtained show a worse correlation for those bins with
Table 5. Fitting parameters for Eq. (3) for different intervals of solar zenith angles.

\begin{tabular}{llll}
\hline$\vartheta_{o}\left({ }^{\circ}\right)$ & $\mathrm{A}$ & $\mathrm{B}$ & $R^{2}$ \\
\hline$(18,28)$ & 1.55 & 0.96 & 0.85 \\
$(28,38)$ & 1.50 & 0.96 & 0.85 \\
$(38,48)$ & 1.87 & 0.91 & 0.82 \\
$(48,58)$ & 2.78 & 0.81 & 0.77 \\
$(58,68)$ & 3.29 & 0.74 & 0.72 \\
$(68,80)$ & 1.45 & 0.99 & 0.53 \\
\hline
\end{tabular}

Table 6. Model results at each location considering solar dependence.

\begin{tabular}{lrrrrr}
\hline Stations & $\begin{array}{r}\mathrm{a} \\
\mathrm{mW} \mathrm{m}^{-2}\end{array}$ & $\mathrm{~b}$ & $R^{2}$ & $\begin{array}{r}\mathrm{MBE} \\
\%\end{array}$ & $\begin{array}{r}\mathrm{RMSE} \\
\%\end{array}$ \\
\hline A Coruña & 1.77 & 0.96 & 0.96 & -1.7 & 17.1 \\
Málaga & 2.77 & 1.02 & 0.97 & 5.8 & 16.7 \\
Murcia & 2.68 & 1.008 & 0.97 & 3.1 & 14.3 \\
Santander & 0.98 & 0.99 & 0.97 & 0.1 & 15.6 \\
Valencia & 3.10 & 1.08 & 0.97 & 12.8 & 22.5 \\
Zaragoza & 1.61 & 0.95 & 0.98 & -3.1 & 13.4 \\
\hline
\end{tabular}

larger solar zenith angles representing a reduced UVER range (Fig. 2). The use of this solar-zenith-angle-dependent model does not improve upon the simple model. Table 6 presents the global results obtained at the different stations using the model with solar zenith angle dependence. The comparison of Tables 4 and 6 reveals that the use of a solarangle-dependent model reduces the underestimation encountered at A Coruña, Santander and Zaragoza, while for the other sites the overestimation increases. After applying an ANOVA test to the estimates from the models with and without solar-zenith-angle dependence we can conclude that, at the 0.01 level, the population variations are not significantly different. Thus, it seems that the use of the model with the solar-zenith-angle dependence does not represent a generalized improvement.

\subsection{Estimation of the UV-index}

In the last years an index (UV index) has been introduced to inform the public of the potentially harmfull effects of the UV-B irradiance. The UV index is determined by multiplying the UVER irradiance in $\mathrm{W} \mathrm{m}^{-2}$ by 40 . For the general public it is usually given as an integer number, i.e. without decimals. Thus the clear sky value at sea level in the tropics would be about $14\left(350 \mathrm{~mW} \mathrm{~m}^{-2}\right)$ and 10 is an exceptionally high value for northern mid-latitudes. UV intensity is described in terms of ranges running from low values (less than 2 ), moderate (3-5), high (6-7), very high (8-10) and 


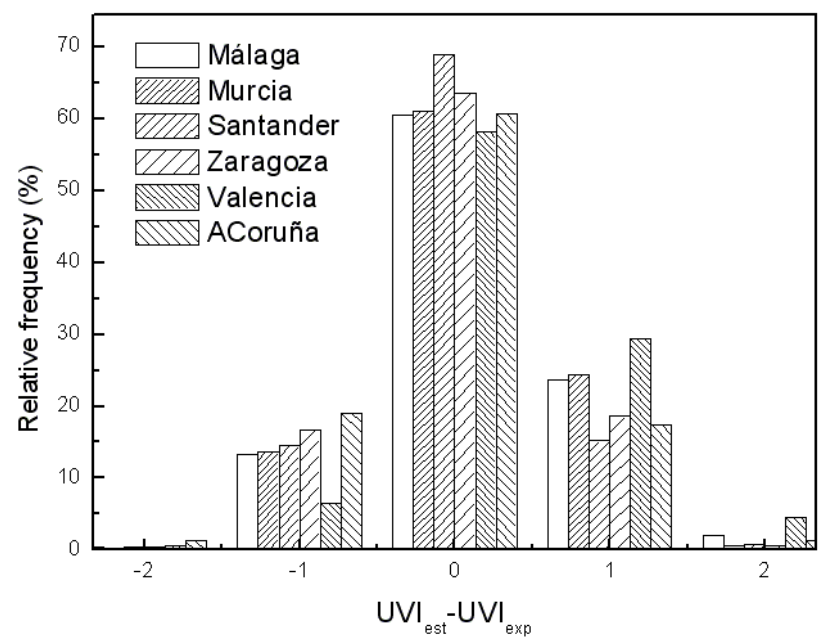

Fig. 5. Histograms of the differences between modeled and estimated experimental UVI, at each location.

extreme (11+). This scale has been adopted by the WMO and WHO and is in use in many countries. In Europe there are currently more than a dozen centers that predict the UV index at a national or regional level (Vanicek at al., 2000). In Spain, the National Institute of Meteorology (INM) has a network composed of 16 measurement stations from which the values of the UV index are determined.

Once the model determined the UVER irradiance, we evaluated the ability of the model to estimate the UV index. Figure 5 shows the relative frequency of the differences between estimated and measured UV index values at each location. We found that the percentage of cases with differences of 0 UVI unit is in the range of $61.1 \%$ to $72.0 \%$ (Valencia and Santander), while the percentage of the cases with differences of \pm 1 UVI unit covers the range $95.6 \%$ (Valencia) to 99.2\% (Zaragoza, Murcia and Santander). This means that in the absence of measured values the estimation of the UV index with the model is acceptable.

\section{Conclusions}

Taking into account that the most important factors influencing UV radiation reaching the ground are solar elevation and cloudiness, and since the cloudiness is both difficult to characterize and highly variable in time and space, we have adapted an empirical model (Foyo-Moreno et al., 1999) in order to estimate the UVER irradiance and the UV index for all-sky conditions.

The simple all-weather model needs only three input parameters: the optical air mass, the total ozone to estimate the UVER irradiance for cloudless skies, and $k_{t}$, the ratio of global horizontal irradiance to extraterrestrial horizontal irradiance, which depends both on cloud cover and aerosol load. Thus, the model does not use direct information about cloudiness. The model was developed considering that if short time scales are involved and an accurate description of the radiation for all cloud conditions is required, then the broadband solar radiation is the best input parameter (Calbó et al., 2005).

The study considered seven stations in the Iberian Peninsula using data recorded in the framework of the Spanish UVB radiometric network. One station (Madrid) was used in the generation of fitting parameters included in the model and an independent database with the remaining stations was employed in the model validation.

The results indicate that the empirical model provides good results. In fact, mean bias errors are less than $4 \%$ and root mean square errors are below $18 \%$ for all but one of the sites (Valencia). The model underestimates the UVER irradiance at three stations (A Coruña, Santander and Zaragoza).

A solar-zenith-angle-dependent version of the model has been considered. In some stations this model improves the UVER estimation while others present worse results. In any case, the ANOVA test suggests that, at the 0.01 level, the estimations provided by both models are not significantly different.

We also have evaluated the model in order to analyze its ability to estimate the UV index which has been defined to inform the public about levels of UV-B radiation incident at ground level and possible harmful effects. The results show that the percentage of cases with differences of 0 UVI units is in the range of $61.1 \%$ to $72.0 \%$, while the percentage of the cases with differences of \pm 1 UVI unit covers the range of $95.6 \%$ to $99.2 \%$. So when measurements are not available we can estimate the UV index using measurements of total ozone and global radiation.

In summary, an empirical model permits estimation of the erythemal UV irradiance and the UV index, at places where the UV-B irradiance is not measured or to extrapolate existing data sets back in time. The model depends on input parameters that are usually available in radiometric networks (solar position and solar broadband irradiance). The ozone data can be easily available from satellites (TOMS data) if ground-based data is not available.

Acknowledgements. This work was supported by CICYT from the Spanish Ministry of Science and Technology through projects CIRRUS REN2003-03175 and PANDORA-CALIPSO CGL200405984-C07-03, REN 2003- 03175 and Andalusian Regional Government project P06-RNM-01503. The "Instituto Nacional de Meteorología" kindly provided the radiometric and meteorological information for the stations used in this study. We are in debt with A. S. Kowalski that revise the manuscript and the anonymous referees that provided some suggestions that help us to improve it.

Topical Editor F. D' Andrea thanks two anonymous referees for their help in evaluating this paper. 


\section{References}

ACS: Cancer Facts and Figures, Publication 95-375, American Cancer Society, Atlanta, GA (USA), 1995.

Alados, I., Mellado, J. A., Ramos, F., and Alados-Arboledas, L.: Estimating UV erythemal irradiance by means of neural networks, J. Photochem. Photobiol., 80(2), 351-358, 2004.

Alados-Arboledas, L., Olmo, F. J., Alados, I., and Pérez, M.: Parametric models to estimate photosynthetically active radiation in Spain, Agric. Forest. Meteorol., 101, 187-201, 2000.

Alados-Arboledas, L., Alados, I., Foyo-Moreno, I., Olmo, F. J., and Alcántara, A.: The influence of clouds on surface UV erythemal irradiance, Atmos. Res., 1102, 1-18, 2003.

ASTM: Standard solar constant and air mass zero solar spectral irradiances tables, E490-73a, American Society for Testing and Materials, 6 pp, 1973.

Bais, A. F., Zerefos, C. S., Meleti, C., Ziomas, I. C., and Tourpali, K.: Spectral measurements of solar UV-B radiation and its relations to total ozone, $\mathrm{SO}_{2}$ and clouds, J. Geophys. Res., 98, 5199-5204, 1993.

Blumthaler, M., Ambach, W., and Salzgeber, M.: Effects of cloudiness on global and diffuse UV irradiance in a high-mountain area, Theor. Appl. Clim., 50, 68-74, 1994.

Blumthaler, M., Ambach, W., Cede, A. A., and Staehelin, J.: Attenuation of erythemal effective irradiance by cloudiness at low and high altitude in the alpine region, J. Photochem. Photobiol., 63, 193-196, 1996.

Bodeker, G. E. and McKenzie, R. L.: An algorithm for inferring surface UV irradiance including cloud effects, J. Appl. Meteorol., 35, 1860-1877, 1996.

Bordewijk, J. A., Slaper, H., Reinen, H. A. J. M., and Schlamann, E.: Total solar radiation and the influence of clouds and aerosols on the biologically effective UV, Geophys. Res. Lett., 22(16), 2151-2154, 1995.

Borkowski, J., Chai, A. T., Mo, T., and Green, A. E. S.: Cloud effects on middle ultraviolet global radiation, Acta Geophys. Pol., XXV(4), 287-301, 1977.

Bryant, E.: Climate Process and Change, 209 pp., Cambridge Univ. Press, New York, 1997.

Brazilian Society of Dermatology Website: http://www.sbd.org.br, National Program of Skin Cancer Control, 2003.

Calbó, J., Pagès, D., and González, J.: Empirical studies of cloud effects on UV radiation: A review, Rev. Geophys., 43, RG2002, doi:10.1029/2004RG000155, 2005.

CIE: Commission Internationale de l'Eclairage, Publication 17.4., 1987.

Den Outer, P. N., Slaper, H., and Tax, R. B.: UV radiation in the Netherlands: assessing long-term variability and trends in relation to ozone and clouds, J. Geophys. Res., 110, D02203, doi:10.1029/2004JD004824, 2005.

Diffey, B. L.: The consistency of studies of ultraviolet erythema in normal human skin, Phys. Med. Biol., 27, 715-720, 1982.

Diffey, B. L.: Solar ultraviolet effects on biological systems, Phys. Med. Biol., 36, 299-328, 1991.

Diffey, B. L.: Stratospheric ozone depletion and the risk of nonmelanoma skin cancer in the British population, Phys. Med. Biol., 37(12), 2267-2274, 1992.

Estupiñán, J. G., Raman, S., Crescenti, G. H., Streicher, J. J., and Barnard, W. F.: Effects of clouds and haze on UV-B radiation, J. Geophys. Res., 101(D11) 16807-16816, 1996.
Foyo-Moreno, I., Vida, J., and Alados-Arboledas, L.: Ground based ultraviolet (290-385 $\mathrm{nm}$ ) and broadband solar radiation measurements in south-eastern Spain, Int. J. Climatol., 18, 1389-1400, 1998.

Foyo-Moreno, I., Vida, J., and Alados-Arboledas, L.: A simple all weather model to estimate ultraviolet solar radiation (290385 nm), J. Appl. Meteorol., 38, 1020-1026, 1999.

Frederick, J. E., Koob, A. E., Alberts, A. D., and Weatherhead, E. C.: Empirical studies of tropospheric transmission the ultraviolet: Broadband measurements, J. Appl. Meteorol., 32, 18831892, 1993.

Frederick, J. E. and Snell, H. E.: Tropospheric influence on solar ultraviolet radiation: the role of clouds, J. Climatol., 3, 373-381, 1990.

Frederick, J. E. and Steele, H. D.: The transmission of sunlight through cloudy skies: An analysis based on standard meteorological information, J. Appl. Meteorol., 34, 2755-2761, 1995.

Fröhlich, C. and London, J. (Eds.): Revised Instruction Manual on Radiation Instruments and Measurements, WCRP Publ. Series No. 7, WMO/TD, 140 pp., 1986.

Grant, R. H. and Heisler, G. M.: Estimation of ultraviolet-B irradiance under variable cloud conditions, J. Appl. Meteorol., 39, 904-916, 2000.

Ilyas, M.: Effects of cloudiness on solar ultraviolet radiation reaching the surface, Atmos. Environ., 21, 1483-1484, 1987.

Josefsson, W. and Landelius, T.: Effect of clouds on UV irradiance: as estimated from cloud amount, cloud type, precipitation, global radiation and sunshine duration, J. Geophys. Res., 105, 49274935, 2000.

Krzyscin, J. W. and Sobolewski, P. S.: The surface UV-B irradiation in the Arctic. Observations at the Polish polar station, Hornsund ( $\left.77^{\circ} \mathrm{N}, 15^{\circ} \mathrm{E}\right)$, J. Atmos. Sol. Terr. Phys., 63, 321-329, 2001.

Kuchinke, C. and Nunez, N.: Cloud transmission estimates of UV-B erythemal irradiance, Theor. Appl. Climatol., 63, 149-161, 1999.

Leszczynski, K., Jokela, K., Ylianttila, L., Visuri, R., and Blumthaler, M.: Erythemally weighted radiometers in solar UV monitoring: results from the WMO/STUK intercomparison, J. Photochem. Photobiol., 67, 212-221, 1998.

Lantz, K. O., Disterhoft, P., de Luisi, J. J., Early, E., Thomson, A., Bigelow, D., and Slusser, J.: Methodology for deriving clear sky erythemal calibration factors for UV broadband radiometers of the U.S. Central UV Calibration Facility, J. Atmos. Ocean. Technol., 16, 1736-1752, 1999.

Lebert, M., Schuster, M., and Hader, M.: The European light dosimeter network: four years of measurements, Photochem. Photobiol., 66, 81-87, 2002.

Lubin, D. and Frederick, J. F.: Ultraviolet radiation environment of the Antarctic Peninsula: The role of ozone and cloud cover, J. Appl. Meteorol., 30, 478-493, 1991.

Lubin, D., Jensen, E. H., and Gies, H. P.: Global surface ultraviolet climatology from TOMS and ERBE data, J. Geophys. Res., 103(D20), 26 061-26 091, 1998.

Ma, J. and Guicherit, R.: Effects of stratospheric ozone depletion and tropospheric pollution on UVB radiation in the troposphere, J. Photochem. Photobiol., 66, 346-355, 1997.

Martínez-Lozano, J. A., Marín, M. J., Tena, F., Utrilla, M. P., Sánchez-Munlosguren, L., Gonzalez-Frías, C., Cuevas, E., Redondas, A., Lorente, J., de Cabo, J., Chamorro, V., Vergez, R., de Frutos, A., Díaz, J. P., Expósito, F. J., de la Morena, B., and 
Vilaplana, J. M.: UV index experimental values during the years 2002 and 2001 from the Spanish broadband UV-B radiometric network, J. Photochem. Photobiol., 76, 181-187, 2002.

McKinlay, A. F. and Diffey, L.: A reference spectrum for ultraviolet induced erythema in human skin, CIE Journal, 6, 17-22, 1987.

Nemeth, P., Toth, Z., and Nagy, Z.: Effect of weather conditions on UV-B radiation reaching the earth's surface, J. Photochem. Photobiol., 32, 177-181, 1996.

Pearson, A. J., Dean, S. F., Clark, I. E., Campbell, J. I., Grainger, K. J., and Driscoll, C. M. H.: NRPB solar ultraviolet radiation measurement network, Radiation Protection Dosimetry, 91, 169$172,2000$.

Sabburg, J. and Wong, J.: Evaluation of a sky/cloud formula for estimating UV-B irradiance under cloudy conditions, J. Geophys. Res., 105, 29685-29691, 2000.

Schafer, J. S., Saxena, V. K., Wenny, B. N., Barnard, W., and de Luisi, J. J.: Observed influence of clouds on ultraviolet-B radiation, Geophys. Res. Lett., 23, 2625-2628, 1996.

Schwander, H., Koepke, P., Kaifel, A., and Seckmeyer, G.: Modification of spectral UV irradiance by clouds, J. Geophys. Res., 107, 10 1029-10 1041, 2002.

Thiel, S., Steiner, K., and Seidlitz, H. K.: Modification of global erythematly effective irradiance by clouds, J. Photochem. Photobiol., 65, 969-973, 1997.

Turnbull, D. J. and Parisi, A. V.: Spectral UV in public shade settings, J. Photochem. Photobiol. B. Biology, 69, 13-19, 2003.

UNEP Report: Environmental effects of ozone depletion: 1998 assessment, J. Photochem. Photobiol. B. Biology, 46, 1-108, 1998.
UNEP Report: Environmental effects of ozone depletion and its interaction with climate change: 2002 assessment, J. Photochem. Photobiol. Science B. Biology, 2, 1-72, 2003.

Van der Leun, J. C., Tevini, M., and Worrest, M. (Eds.): Environmental Effects of Ozone Depletion: 1991 Update, United Nations Environmental Programme, Nairobi, 1991.

Van der Leun, J. C., Tevini, M., and Worrest, M. (Eds.): Environmental. Effects of Ozone Depletion: 1994 Update, United Nations Environmental Programme, Nairobi, 1994.

Van der Leun, J. C., Tevini, M., and Worrest, M. (Eds.): Environmental Effects of Ozone Depletion: 1998 Update, United Nations Environmental Programme, Nairobi, 1998.

Vanicek, K., Frei, T., Litynska, Z., and Schnalwieser, A.: UV-Index for the public, COST 713- Action (UV-B forecasting), Brussels, 2000.

WHO: Protection against exposure to ultraviolet radiation, Report WHO/EHG/95, World Health Organisation: Geneva, 17, 1995.

WMO: Scientific Assessment of Ozone Depletion: 1998, Global Ozone Research and Monitoring Project, Report No. 44, 1998.

Zerefos, Z., Balis, D., Tzortziou, M., Bais, A., Tourpali, K., Meleti, C., Bernhard, G., and Herman, J.: A note on the interannual variations of UV-B erythemal doses and solar irradiances from ground-based and satellite observations, Ann. Geophys., 19, 115-120, 2001,

http://www.ann-geophys.net/19/115/2001/. 